\title{
Biomimetic Ca-P Coatings Incorporating Bisphosphonates Produced on Starch-Based Degradable Biomaterials
}

\author{
A. L. Oliveira, ${ }^{1,2,3}$ A. J. Pedro, ${ }^{1,2}$ C. Saiz Arroyo, ${ }^{1,2}$ J. F. Mano, ${ }^{1,2}$ G. Rodriguez, ${ }^{3}$ \\ J. San Roman, ${ }^{3}$ R. L. Reis ${ }^{1,2}$ \\ 1 3B's Research Group - Biomaterials, Biodegradables and Biomimetics, University of Minho, Headquarters of the \\ European Institute of Excellence on Tissue Engineering and Regenerative Medicine, Guimarães, Portugal \\ ${ }^{2}$ Institute for Biotechnology and Bioengineering, PT Associated Laboratory, Guimarães, Portugal \\ ${ }^{3}$ Macromolecular Chemistry Department, Institute of Polymer Science and Technology, CSIC, \\ 28006 Madrid, Spain
}

Received 11 February 2008; revised 10 March 2009; accepted 3 April 2009

Published online 21 August 2009 in Wiley InterScience (www.interscience.wiley.com). DOI: 10.1002/jbm.b.31489

\begin{abstract}
In this study, sodium clodronate, a well-known therapeutic agent from the family of bisphosphonates (BPs), is incorporated in a biomimetic calcium phosphate (CaP) coating, previously formed on the surface of a starch-based biomaterial by a sodium silicate methodology, as a strategy to develop a site-specific drug delivery system for bone tissue regeneration applications. The effects on the resulting $\mathrm{CaP}$ coatings were evaluated in terms of morphology, chemistry, and structure. The dissolution of $\mathrm{Ca}$ and $\mathrm{P}$ from the coating and the release profiles of sodium clodronate was also assessed. As a preliminary approach, this first study also aimed at evaluating the effects of this BP on the viability of a human osteoblastic cell line since there is still little information available on the interaction between BPs and this type of cells. Sodium clodronate was successfully incorporated, at different doses, in the structure of a biomimetic CaP layer previously formed by a sodium silicate process. This type of BPs had a stimulatory effect on osteoblastic activity, particularly at the specific concentration of $0.32 \mathrm{mg} / \mathrm{mL}$. It is foreseen that these coatings can, for instances, be produced on the surface of degradable polymers and then used for regulating the equilibrium on osteoblastic/osteoclastic activity, leading to a controlled regenerative effect at the interface between the biomaterial and bone. (C) 2009 Wiley Periodicals, Inc. J Biomed Mater Res Part B: Appl Biomater 92B: 55-67, 2010
\end{abstract}

Keywords: biodegradable polymers; starch; biomimetic coating; calcium phosphate; sodium silicate; bisphosphonate; drug therapy

\section{INTRODUCTION}

Although remarkable progresses have been made to produce superior bone-like materials, the right balance between surface and bulk properties is still to be achieved. At present, one of the most interesting solutions to this problem is to use calcium phosphates ( $\mathrm{CaPs}$ ) as coatings on the surface of biomaterials. In addition, due to their osteogenic potential, $\mathrm{CaP}$ layers can be used as drug-carrier systems in bone tissue engineering applications., ${ }^{1,2}$ Recently, $\mathrm{CaP}$ layers were deposited on the surfaces of metal implants under highly unphysiological conditions. Therefore, it was not possible to coat polymeric substrates or to incorporate a bioactive agent. Plasma spraying, for exam-

Correspondence to: A. L. Oliveira (e-mail: analeite@dep.uminho.pt) (C) 2009 Wiley Periodicals, Inc. ple, is a commercially available technique in which high processing temperatures are used. ${ }^{3-7}$

At present, it is possible to produce $\mathrm{CaP}$ layers under physiological conditions of temperature, $\mathrm{pH}$, and pressure, using the so-called biomimetic process. $^{8-15}$ As a result, there are new opportunities for applying this type of coatings in the field of tissue engineering, as a way to enhance cell adhesion and proliferation and extracellular matrix production. On the other hand, new possibilities for incorporating bioactive molecules, such as synthetic drugs or proteinaceous osteoinductive molecules, are being considered. $^{2}$ Because of the slow, but definite, degradation of CaPs, as well as their high hydrophilicity, ${ }^{16}$ they can be very suitable to serve as carriers for these molecules.

Research envisioning $\mathrm{CaP}$ coatings as carrier systems for the release of therapeutic molecules is still scarce, but its potential have captured the attention of some groups in the recent years. For example, antibiotic loading into $\mathrm{CaP}$ 
coatings on bone-replacement materials is a clinically relevant concept in the setting of total joint arthroplasty and has been addressed recently. Radin et al. ${ }^{17}$ have accomplished the loading of vancomycin by immersion of ceramic-coated discs in vancomycin-containing simulated physiological solution. In a study performed by Campbell et al., ${ }^{18}$ chlorhexidine was incorporated into an apatite coating by placing the substrate into various chlorhexidine solutions in between mineralization cycles. CaP coatings containing tobramycin were produced by Stigter et al. ${ }^{19}$ on titanium alloy (Ti6Al4V) implants, using a biomimetic approach. Although the options for creating a delivery system in these coatings can be numerous, the affinity of a specific molecule to the $\mathrm{CaP}$ crystals as well as its size, charge, or conformation, are crucial features for an effective incorporation. In fact, some of these agents, because of their chemical structure or conformation, can only be adsorbed superficially, on preformed layers. Such superficially adsorbed molecules are sometimes released too rapidly within a biological milieu to be effective in their therapeutic/osteoinductive capacity.

Bisphosphonates (BPs) are an important family of drugs in various bone- and calcium-related pathologies, such as cancer, ${ }^{20}$ hypercalcemia, ${ }^{21}$ Paget's disease, ${ }^{22}$ or osteoporosis. $^{20-26}$ The affinity of BPs to bone mineral hydroxyapatite (HA) is the basis for their use as inhibitors of bone resorption. $^{25,26}$ They are pyrophosphate $(\mathrm{P}-\mathrm{O}-\mathrm{P})$ analogs in which the oxygen in the $\mathrm{P}-\mathrm{O}-\mathrm{P}$ has been replaced by a carbon to yield a $\mathrm{P}-\mathrm{C}-\mathrm{P}$ backbone. Substitutions on the carbon give rise to a large family of compounds with different properties and potencies, which are determined by the nature of the side chains. ${ }^{26}$ The physicochemical effects of BPs include binding strongly to the CaP crystals and inhibiting their growth, aggregation, and dissolution. ${ }^{25-27}$ Their biological effects in calcium-related disorders are due to the direct interaction with osteoclasts ${ }^{28}$ and/or osteoblasts. ${ }^{29}$ It is now generally accepted that BPs inhibit osteoclast activity. ${ }^{23-25,29}$ However, the major drawback of the clinically used BPs is their pharmacokinetics and poor oral absorption from the gastrointestinal tract, which is typically less than $1 \% .^{25,26} \mathrm{In}$ addition, BPs have been associated with adverse gastrointestinal effects in humans. ${ }^{30}$ The attempts to improve the bioavailability of BPs had only very limited success because of a lack of marked improvement of adsorption and/or side effects. ${ }^{30}$ The challenge for novel drug delivery systems is to achieve improved bioavailability and safety. In addition to oral administration, different strategies have been proposed over the last years, such as nasal delivery ${ }^{31}$ and subcutaneous ${ }^{32-34}$ or intramuscular injection. ${ }^{35}$

In addition to being used in the treatment of the pathologies described earlier, it has been also discovered ${ }^{36-38}$ that BPs can be beneficial when administrated after bone replacement, decreasing the primary failure mode of total hip arthroplasty, which is aseptic loosening following periimplant osteolysis. Nevertheless, this effect could be improved if the time delay for the BP to reach the boneimplant interface could be reduced. In this case, a localized delivery of the drug could have a favorable effect to produce a more stable and integrated interface between the implant and the bone at the early stage of implantation, when a significant bone loss can occur. ${ }^{39}$ In fact, this was already attempted with success in several studies using different BPs. ${ }^{39-42}$ For example, Kajiwara et al. ${ }^{40}$ have treated calcium ion-implanted titanium implants with pamidronate, which significantly accelerated new bone formation in a rat tibia. Yoshinari et al. ${ }^{41}$ have studied the effect of the same BP incorporated in a plasma-sprayed HA-coated titanium dental implant in beagle mandibular bone, increasing the bone-implant contact area. Recently, Peter et al. ${ }^{42}$ have grafted zoledronate to plasma-sprayed HA coating of titanium implants that were then inserted in rat condyles. A positive concentration-dependent effect was observed on the peri-implant bone density and on different histomorphometric parameters.

Because of its reported effects on bone, one can envision that to incorporate a $\mathrm{BP}$ in a bone-like CaP-coated biodegradable scaffold can be a very promising strategy for designing a site-specific drug delivery system in a tissue engineering approach, by locally enhancing tissue integration and regeneration. In this study, sodium clodronate, a well-known BP, was physically incorporated at different doses in a CaP coating, previously formed on the surface of a starch-based biomaterial by a sodium silicate methodology. The effects on the resulting $\mathrm{CaP}$ coatings were evaluated in terms of morphology, chemistry, and structure. The release profile of the drug and the stability of the coatings were assessed at different physiological environments. As a preliminary approach, this study also aimed at screening the ideal sodium clodronate dose to be incorporated in the CaP coatings, which is able to elicit positive effects on the viability, growth, and function of a human osteoblasticlike cell line. In fact, there is still little information available on the interaction between BPs and this type of cells.

\section{MATERIALS AND METHODS}

\section{Preparation of the Samples}

As a natural polymer with rather interesting properties, ${ }^{43-45}$ starch exhibits a great potential to be used in biomedical applications. The studied material is based on a blend of starch and ethylene vinyl alcohol (SEVA-C). The blend contains around $50 \%$ starch by weight, while the copolymer discloses a composition of $60 / 40 \mathrm{~mol} / \mathrm{mol}$. Compact samples were produced by injection molding on a Klockner Desma FM-20, using a nozzle temperature of $170^{\circ} \mathrm{C}$. All the samples were shaped into the form of disks with a diameter of $10 \mathrm{~mm}$. Further information on the properties of starch-based polymers and its potential for biomedical applications may be found elsewhere. ${ }^{43-46}$ 


\section{Sodium Silicate Methodology}

To produce the bioactive coatings, a commercially available sodium silicate gel from Sigma-Aldrich $\left(\mathrm{Na}_{2} \mathrm{SiO}_{3} \cdot \mathrm{H}_{2} \mathrm{O}\right.$, containing $\sim 14 \% \mathrm{NaOH}$ and $\sim 27 \% \mathrm{SiO}_{2}$, $\mathrm{pH} 13$ was used). The sodium silicate gel was used with concentration and $\mathrm{SiO}_{2} / \mathrm{Na}_{2} \mathrm{O}$ molar ratio as received. ${ }^{15}$ The viscosity of the gel is $6 \times 10^{-2} \mathrm{~Pa}_{\mathrm{s}}{ }^{-1}$. This high viscosity allowed for the impregnation other than uptaking the gel into the polymer, which would affect the mechanical and degradation behavior of the material. The materials (SEVA-C disks with a diameter of $10 \mathrm{~mm}$ ) were "impregnated" for $24 \mathrm{~h}$ with the gel, in a controlled atmosphere $\left(23 \pm 1{ }^{\circ} \mathrm{C} ; 55 \% \mathrm{RH}\right)$. After this treatment, the gel with the samples was diluted with $50 \%$ vol. of distilled water and stirred for $5 \mathrm{~min}$. This procedure was aimed at diminishing the viscosity of the gel to produce a homogeneous and thin layer of vitrified sodium silicate in the surface of the materials. The samples were then removed from the solution and dried in a controlled atmosphere $\left(23 \pm 1{ }^{\circ} \mathrm{C} ; 55 \% \mathrm{RH}\right)$.

\section{Apatite Formation}

An aqueous solution was prepared comprising all major inorganic ions present in human blood plasma and presenting its approximate ion concentration, to promote in vitro apatite formation. The different salts were dissolved in deionized $\mathrm{H}_{2} \mathrm{O}$, and the $\mathrm{pH}$ was adjusted to neutral using tris(hydroxymethyl)aminomethane and hydrochloric acid. This simulated body fluid (SBF) solution was developed by Kokubo et al. ${ }^{11}$

The treated samples were first soaked in SBF to nucleate the CaP layer, and after 7 days, soaked in another solution, with ion concentrations $1.5 \times \mathrm{SBF}$ for allowing this layer to grow. The solutions were renewed every 2 days during the coating process, which lasted for 14 days. The average thickness of the $\mathrm{CaP}$ layers formed by this methodology is $\sim 2.5 \mu \mathrm{m}$ (measured from the basis of the CaP nuclei to the interface, according to a previously developed method ${ }^{47}$ ).

\section{Incorporation of Sodium Clodronate}

BPs are stable analogs of pyrophosphate in which the $\mathrm{P}-\mathrm{O}-\mathrm{P}$ structure is replaced by a $\mathrm{P}-\mathrm{C}-\mathrm{P}$ structure. Side chains $R^{1}$ and $R^{2}$ are attached to the geminal carbon atom. The BP used in this study was a sodium clodronate in which $R^{1}$ and $R^{2}$ are replaced by chloride. The structure of this drug is shown in Figure $1 .{ }^{48}$

Sodium clodronate (dichloromethylene-BP) is one of the best documented BP that is used effectively in medical applications. ${ }^{48}$ In the literature, the ideal concentration of this BP for inducing a positive effect in bone cells varies from study to study. Therefore, we have chosen two lower concentrations that are considered to be in the therapeutic range $^{48}$ and two higher concentrations to scale up the effects of this $\mathrm{BP}$ in the structure of the $\mathrm{CaP}$ coating so

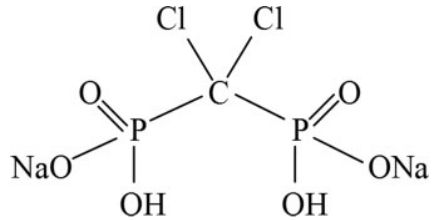

Figure 1. Chemical structure of sodium clodronate. ${ }^{48}$

that could be detectable by infra red and x-ray spectroscopies. Solutions of $0.064,0.32,8$, and $16 \mathrm{mg} / \mathrm{mL}$ of sodium clodronate (Sigma-Aldrich) were prepared with the $\mathrm{pH}$ adjusted to 7.4 using $\mathrm{NaOH}(1 \mathrm{M})$. Aliquots of $50 \mu \mathrm{L}$ of each solution were added to the coated disks left for $3 \mathrm{~h}$, followed by drying at $60^{\circ} \mathrm{C}$. This procedure has been previously reported elsewhere. ${ }^{49}$ The effective concentration of the $\mathrm{BP}$ in the coated samples is approximately as follows: $0.004,0.02,0.5$, and $1 \mathrm{mg} / \mathrm{cm}^{2}$.

\section{Structural and Morphological Characterization}

The morphological characterization was performed by scanning electron microscopy (SEM) analysis in a LEICA Cambridge S360, United Kingdom. All the samples were coated with a thin film of carbon, by ion sputtering, before any observation. The electron beam energy was $15 \mathrm{keV}$. Energy dispersive spectroscopy (EDS) was performed qualitatively in a Rontec spectrometer, to obtain the compositional profiles of the $\mathrm{CaP}$ layers incorporating different amounts of sodium clodronate. Fourier transform infrared spectroscopy with attenuated total reflectance (FTIR-ATR) was performed, aiming at detecting any type of chemical modification on the samples chemical structure. The acquisition was performed in transmittance mode from 4000 to $500 \mathrm{~cm}^{-1}$. All spectra were recorded using 64 scans and $2 \mathrm{~cm}^{-1}$ resolution in an FTIR spectrophotometer (Perkin-Elmer 1600 Series). Thin-film X-ray diffraction (TF-XRD; Philips X'Pert MPD, The Netherlands) was used to identify the crystalline phases present in the $\mathrm{CaP}$ layers formed during the immersion in SBF and after incorporating sodium clodronate. The data collection was performed by $2 \theta$ scan method with $1^{\circ}$ as incident beam angle using $\mathrm{CuK} \alpha$ $\mathrm{X}$-ray line and a scan speed of $0.05^{\circ} / \mathrm{min}$ in $2 \theta$.

\section{Mechanical Behavior}

Microhardness tests are usually regarded as a convenient means of investigating the mechanical properties of materials in a localized and nondestructive manner. Microhardness measurements have been used, herein, to study the differences and correlation between the composition and the surface or coatings in different kinds of samples. The motivations of such measurements are to probe the mechanical environment that the cells will feel when in contact with the material, and to evaluate the influence of the presence of the drug in the coating in its 
TABLE I. Solutions Used in the Dissolution Studies

\begin{tabular}{|c|c|c|}
\hline Solution No. & Description & $\begin{array}{c}\mathrm{pH} \\
\text { (at } 37^{\circ} \mathrm{C} \text { ) }\end{array}$ \\
\hline 1 & Simulated Tris- $\mathrm{HCl}$ solution & 7.4 \\
\hline 2 & $\begin{array}{l}\text { Acidic buffered solution } \\
\text { ( simulating osteoclastic activity) }\end{array}$ & 3 \\
\hline
\end{tabular}

mechanical properties. A Leica VMHT30 equipment was used to measure the microhardness of the samples at room temperature $\left(\sim 20^{\circ} \mathrm{C}\right)$, using a Vickers diamond pyramid indented (included angle $\alpha=136^{\circ} \mathrm{C}$ ). The microhardness, $H_{\mathrm{v}}$, was calculated from the residual projected diagonal impression, using $H_{\mathrm{v}}=1.854 \mathrm{~F} / \mathrm{d}^{2}$ equation, where $d$ is the mean diagonal length of the indentation in millimeter and $F$ the applied force in Newton. A load of $9.807 \mathrm{mN}$ was applied during $10 \mathrm{~s}$ in all tests. These conditions were chosen for getting measurements only at level of the coating, avoiding the bulk of the substrate samples. Fifteen measurements at randomly selected places around coating of each sample were taken in each condition. The same procedure was followed for the samples' substrate.

\section{Dissolution Behavior}

To try to predict the behavior of the $\mathrm{CaP}$ coating when facing the biological milieu is of extreme importance. However, to design a method capable of fully replicating it is extremely difficult, considering the complexity of the biological fluids, going from minerals to proteins, enzymes, and cells. In vitro dissolution tests, although far from the ideal method, can give some insights on the stability of the materials before implantation. In fact, because these studies are performed in solution, they always simulate the worst case low-end service environment.

Dissolution tests were performed on the coated samples before and after loading with increasing doses of sodium clodronate. Two different media were used in this study, according to the International Standard ISO/DIS 10993-14 procedure and are presented in Table 1.

Solution 1 simulates, in a very simplistic way, the in vitro physiological environment. Solution 2 is aimed at reproducing the worse predictable scenario in which the bone is resorbed due to osteoclastic activity. The coated disks, incorporating different amounts of sodium clodronate, were immersed in a volume of $5 \mathrm{~mL}$ of each solution. Two replicates of each condition were studied. The experiment was performed at $37^{\circ} \mathrm{C}$ for periods up to 15 days. Aliquots of $2 \mathrm{~mL}$ were removed at different periods and replaced by the same volume of fresh solution. The obtained samples were analyzed by induced coupled plasma emission spectroscopy for the quantification of $\mathrm{Ca}$ and $\mathrm{P}$. The final cumulative concentration values were calculated according to the following equation:

$$
\sum\left[V_{n}-\left(V_{n-1} * 2 / 5\right)\right]_{n}
$$

$V_{n}$ - volume aliquoted;

$V_{n-1}-$ subsequent volume aliquoted;

\section{Sodium Clodronate Release Studies}

The release of sodium clodronate from the CaP coatings in the previously described solutions was studied. The analyzed solutions and periods of time were the same in which $\mathrm{Ca}$ and $\mathrm{P}$ were quantified. The release of the drug was monitored by means of high-permeation liquid chromatography (HPLC). The analysis was performed by using a mixture (60:40) of methanol/aqueous solution of PIC A (a solution of tetrabutylammonium hydrogen sulfate in water, supplied by Waters) as the mobile phase and a flow rate of $1 \mathrm{~mL} / \mathrm{min}$. The system consisted of a Perkin-Elmer LC250 pump, an UV/vis detector Perkin-Elmer LC-95, and a Waters $\mu$ Boundapak C-18 column of $3.9 \times 300 \mathrm{~mm}$. Measurements were made at $204 \mathrm{~nm}$. Under these conditions,

\section{a. HPLC profile in buffered solution $(\mathrm{pH}=7,4)$}

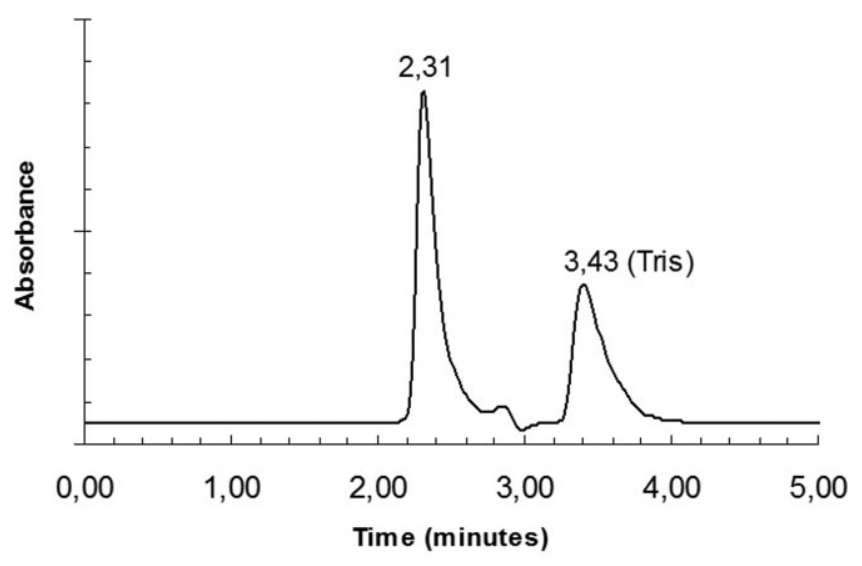

b. HPLC profile in buffered solution $(\mathrm{pH}=3)$

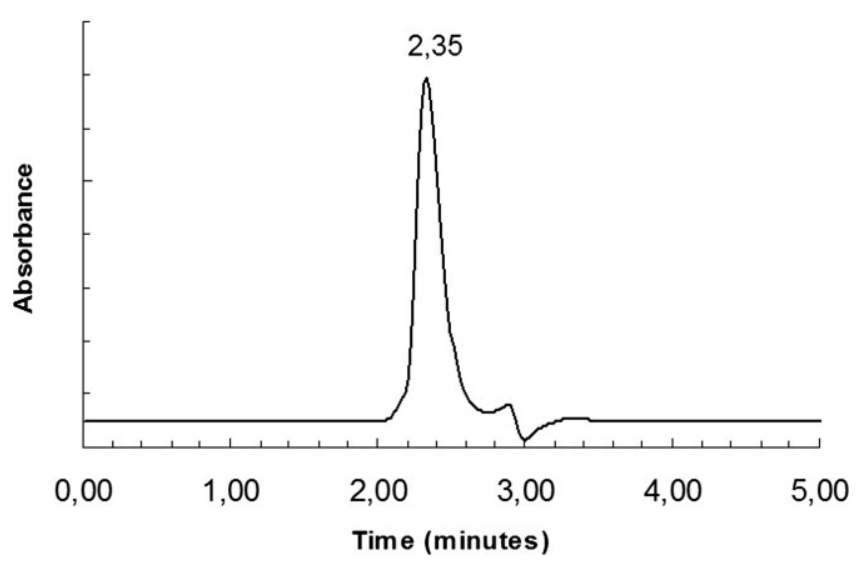

Figure 2. HPLC release profiles of sodium clodronate in (a) a solution buffered to $\mathrm{pH} 7.4$ and (b) a solution buffered to $\mathrm{pH} 3$. 
sodium clodronate presented a retention time of 2.31 and $2.35 \mathrm{~min}$ in $\mathrm{pH}=7.4$ and $\mathrm{pH}=3$, respectively. The obtained profiles for each solution are presented in Figure 2.

Release studies were performed from discs loaded with $8 \mathrm{mg} / \mathrm{mL}$ solutions of sodium clodronate, which provided an effective concentration of $0.4 \mathrm{mg}$ of drug per coated disk. Discs prepared with lower concentration of drug $(0.32$ and $0.064 \mathrm{mg} / \mathrm{mL}$ ) were not evaluated because they are below the detection limit of the HPLC equipment. The effective concentration loaded was $0.4 \mathrm{mg}$ per coated disk, which is the result of a $50-\mu \mathrm{L}$ aliquot of a solution with concentration $8 \mathrm{mg} / \mathrm{mL}$. The results were plotted in accordance with Eq. (1).

\section{Preliminary Evaluation of Cell Adhesion and Proliferation}

To study the morphology, attachment, and proliferation of osteoblast-like cells over precalcified loaded SEVA-C surfaces, a human osteoblast-like cell line (SaOs-2) obtained from the European Collection of Cell Cultures was selected. Dulbecco's modified eagle's medium (Sigma), supplemented with $10 \%$ fetal bovine serum (FBS, Biochrome, Germany) and 1\% antibiotic/antimycotic solution (Sigma) was used as cell incubation medium, and growth to confluence in controlled atmosphere conditions $\left(37^{\circ} \mathrm{C}, 5 \% \mathrm{CO}_{2}, 100 \%\right.$ humidity). Detachment of confluent low passage cells was performed using $0.25 \%$ trypsin/ EDTA solution (Sigma). Subsequently, osteoblast-like cells were cultured over samples in a concentration of $3.3 \times 10^{4}$ cell/mL and incubated for 3, 5, and 7 days in controlled atmospheric conditions. Tissue culture grade polystyrene was used as control and replicates were prepared. After each incubation period, samples were washed with phosphate-buffered saline (Sigma) solution and fixed in gluteraldehyde $2.5 \%(\mathrm{v} / \mathrm{v})$ for observation by means of scanning electronic microscopy. After fixation, samples were dehydrated in crescent ethanol concentrations (50, 70, 90, and $100 \%$ ), air dried, and sputter coated with gold.

Cell viability was measured through the MTS test, using the CellTiter $96^{\circledR}$ AQueous One Solution from Promega, which is based on bioreduction of a substrate (MTS) into a brown product by dehydrogenase enzymes in metabolically active cells, and it is commonly used for cell viability evaluation. Cells were then incubated for $3 \mathrm{~h}$ at $37^{\circ} \mathrm{C}$ in a humidified atmosphere containing $5 \% \quad \mathrm{CO}_{2}$. At this time, optical density (OD) was measured with a plate reader at $490 \mathrm{~nm}$. The mean OD value obtained for the positive control (cell seeded on culture plate without any coating) was considered as $100 \%$ metabolic activity.

\section{RESULTS}

\section{Morphology, Crystallinity, and Chemical Structure of the CaP Coatings}

The effect of the incorporation of different doses of sodium clodronate on the morphology, crystallinity, and chemical structure of the biomimetic coatings was evaluated using SEM/EDS, TF-XRD, and FTIR-ATR techniques. In Figure 3 is presented the morphology of the $\mathrm{CaP}$ coatings grown on the surface of SEVA-C samples before and after a treatment with sodium clodronate at $8 \mathrm{mg} / \mathrm{mL}$. The
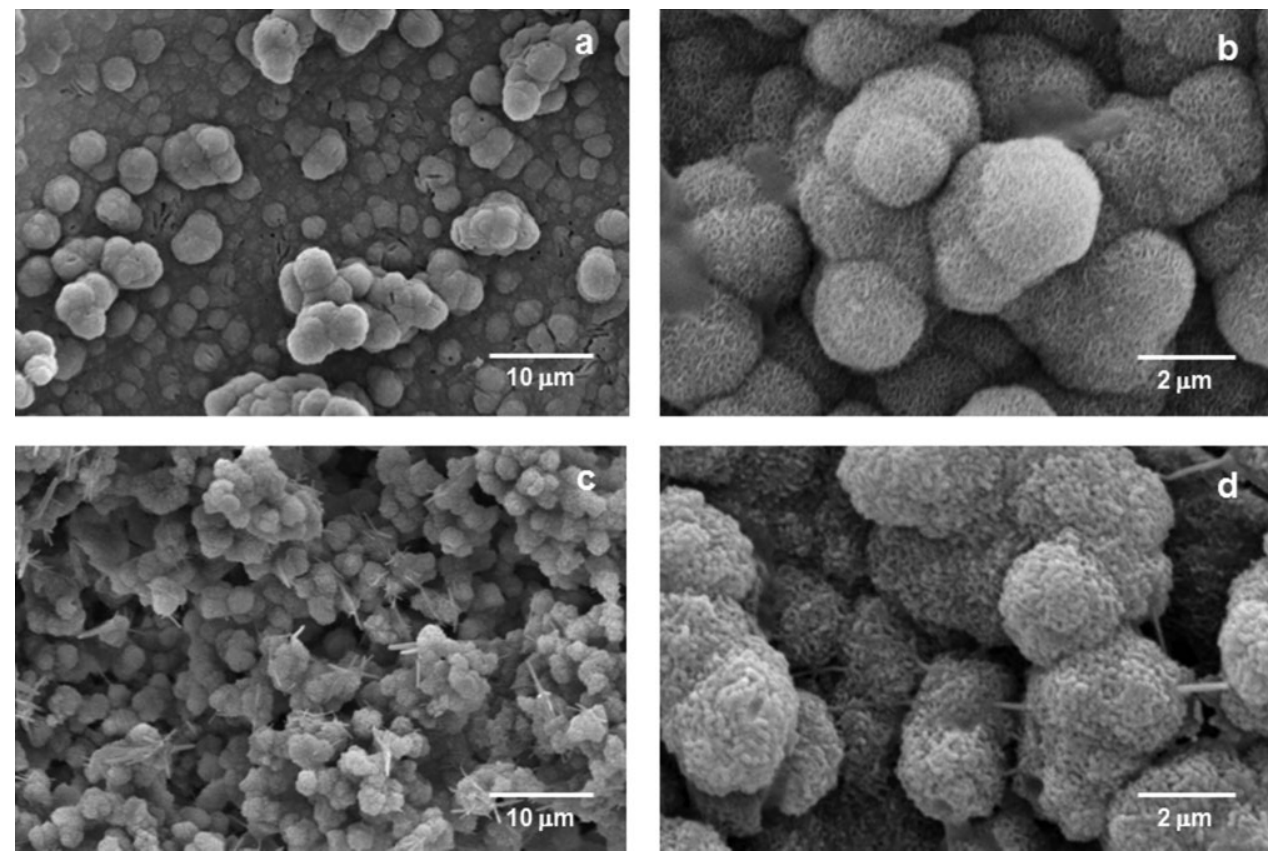

Figure 3. SEM micrographs performed on the apatite coatings grown on the surface of SEVA-C samples $(a, b)$ before and $(c, d)$ after the treatment with $8 \mathrm{mg} / \mathrm{mL}$ of sodium clodronate. 


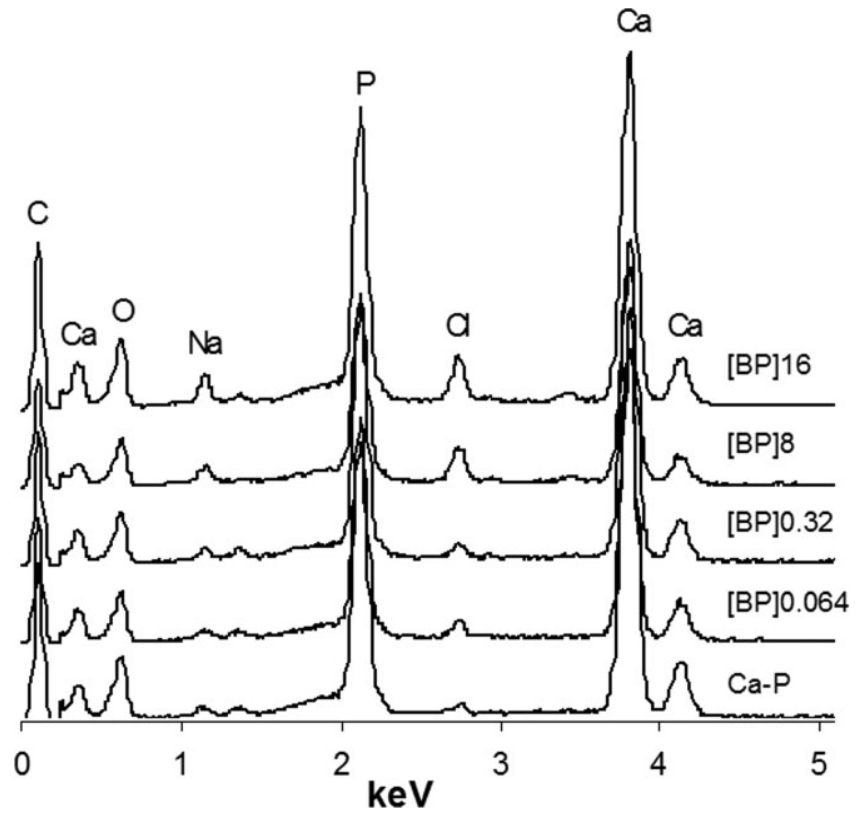

Figure 4. EDS spectra showing the evolution of the elemental composition of the apatite layers with increasing doses of sodium clodronate.

corresponding EDS spectra showing the evolution of the elemental composition are presented in Figure 4.

The use of sodium silicate biomimetic coating methodology resulted in the formation of a $\mathrm{CaP}$ layer on the surface of SEVA-C after 15 days in SBF, exhibiting a nanocrystalline needle-like structure, as presented in Figure $3(\mathrm{a}, \mathrm{b})$. After incorporating the lowest concentrations studied of sodium clodronate, that is, 0.064 and $0.32 \mathrm{mg} / \mathrm{mL}$, the $\mathrm{CaP}$ crystallites did not present any observable modification in their morphology. Therefore, the micrographs presented in Figure $3(a, b)$ are representative of the obtained morphologies in these cases. When incorporating the highest studied concentrations of the BP ( 8 and $16 \mathrm{mg} / \mathrm{mL}$ ), well-defined spicule crystallites started to grow on the surface of the $\mathrm{CaP}$ layer, as it can be visible by examining Figure $3(\mathrm{c}, \mathrm{d})$, for the case where a solution containing $8 \mathrm{mg} / \mathrm{mL}$ was used. By performing localized EDS, it was possible to confirm that the elemental composition of these structures exhibited a high content in $\mathrm{Cl}$, which is assigned to sodium clodronate (data not shown). On the other hand, by observing the surface of the $\mathrm{CaP}$ layer in greater detail [Figure 3(d)], it is also possible to find a modification in its morphology. The resulting $\mathrm{CaP}$ crystals present a more "worm-like" morphology when comparing with the original "needle-like" shape [Figure 3(b)]. This modification can be attributed to a partial dissolution at the surface of the $\mathrm{CaP}$ layer in the presence of the solutions containing high concentrations of sodium clodronate (by calcium depletion) and further reprecipitation under these new conditions, which differ from those present in SBF in terms of composition, ionic strength, and buffer capability. On the other hand, because of its high affinity for $\mathrm{Ca}$ compounds (especially to $\mathrm{CaPs}^{25,26}$ ), the chemical incorporation of the drug onto the $\mathrm{CaP}$ structure, to a certain extent, is also predictable, causing dimensional rearrangements.

In Figure 5 is plotted the FTIR spectra performed on the surface of SEVA-C before and after growing an $\mathrm{CaP}$ layer and after incorporating the highest doses studied of sodium clodronate. Again, by this technique, it was not possible to detect the presence of $\mathrm{BP}$ in the samples treated with the lowest concentrations of the drug. The IR spectrum of sodium clodronate powder is also presented as a reference for identifying its characteristic peaks.

SEVA-C presents - C-O-C - bands at 1015-1140 $\mathrm{cm}^{-1}$, which are characteristic of the glycosidic bonds from starch. ${ }^{50,51}$ After coating the biomimetic layer, it is possible to detect the typical bands of CaPs. The bands at 864,1406 , and $1434 \mathrm{~cm}^{-1}$ result from the presence of carbonate $\left(\mathrm{CO}_{3}^{2-}\right)$ chemically incorporated in the $\mathrm{CaP}$ lattice. $^{52}$ These bands clearly indicate that a carbonated $\mathrm{CaP}$ was formed, as it is found in bone apatite and as reported for other biomimetic coating methods. ${ }^{13,53}$ The bands at 578 and 598 are assigned to the $v_{4}$ bending mode of the $\mathrm{O}-\mathrm{P}-\mathrm{O}$ bonds in the apatite, indicating some degree of crystallinity. The band at $1012 \mathrm{~cm}^{-1}$ indicates the $v_{3}$ stretching mode of $\mathrm{P}-\mathrm{O}$ bonds. ${ }^{52}$ When sodium clodronate is present, besides the major $\mathrm{P}-\mathrm{O}$ bond attributed to the $v_{3}$ vibration of $-\mathrm{PO}_{4}$, additional bands attributed to the same

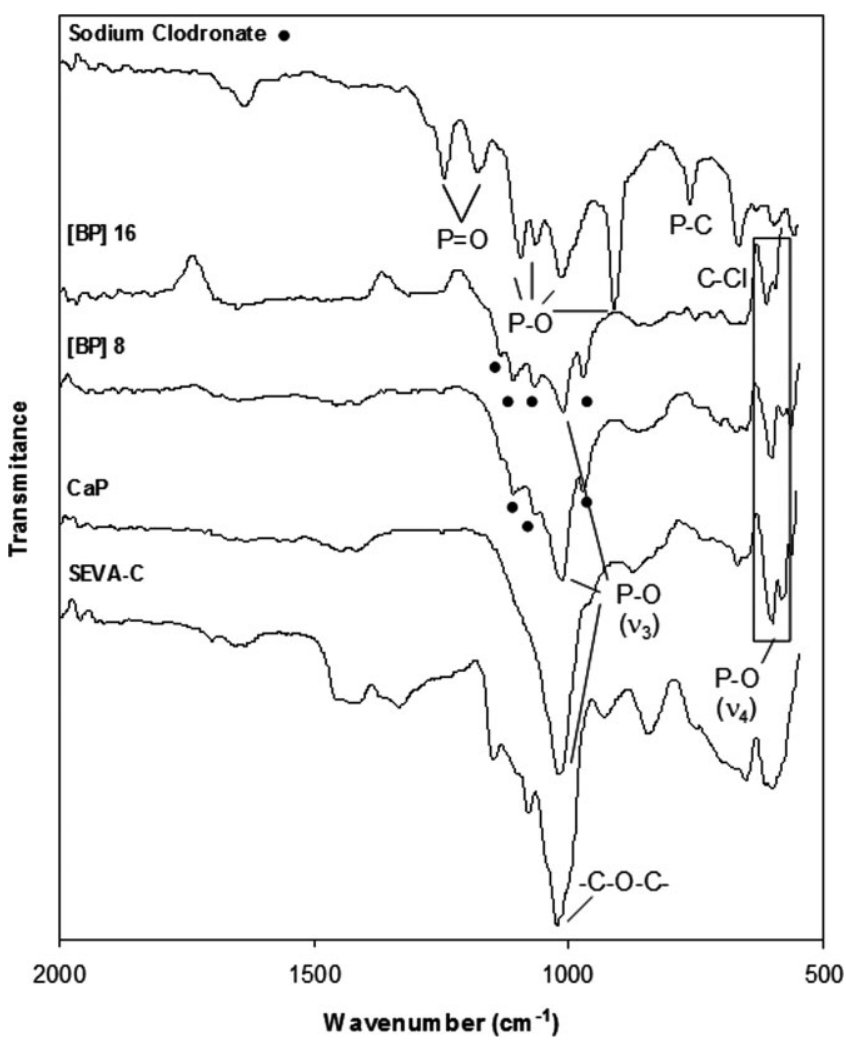

Figure 5. FTIR-ATR spectra of SEVA-C before and after forming an apatite layer and after the incorporation of 8 and $16 \mathrm{mg} / \mathrm{mL}$ of sodium clodronate. Sodium clodronate powder was used as reference. 


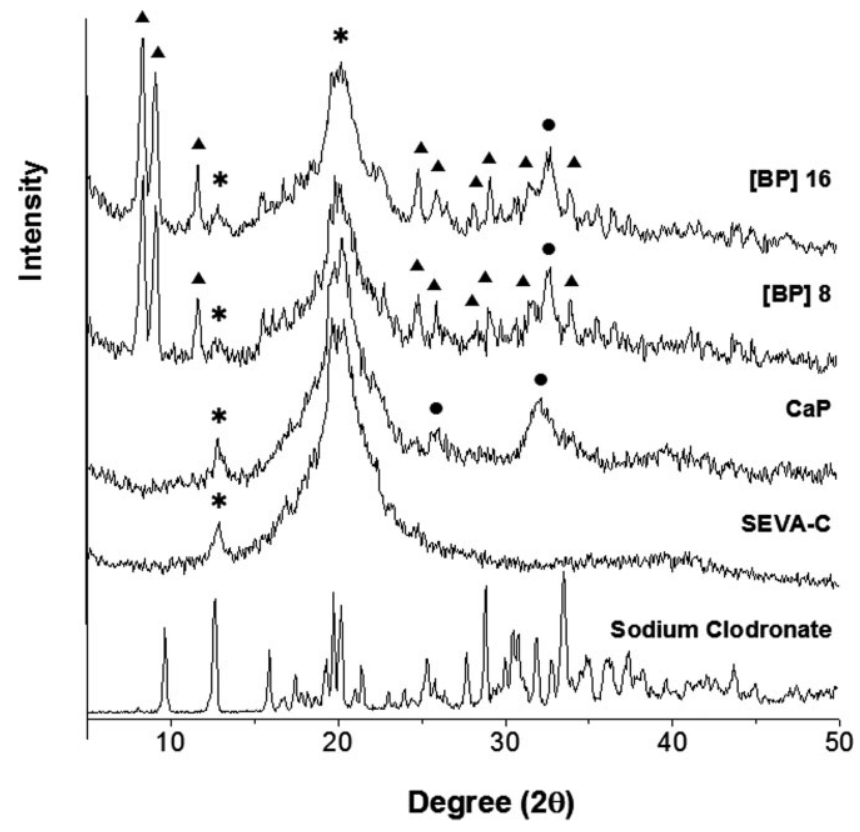

Figure 6. TF-XRD spectra of SEVA-C before and after forming an apatite layer and after the incorporation of 8 and $16 \mathrm{mg} / \mathrm{mL}$ of sodium clodronate. Sodium clodronate powder was used as reference. * SEVA-C; - Apatite; $\boldsymbol{\Delta}$ Sodium clodronate.

type of bonds are detected at 968, 1060, 1102, and 1122 $\mathrm{cm}^{-1}$. The crystallites newly formed on the CaP layer and detected by SEM can then be assigned to the precipitation of the sodium clodronate.

Figure 6 presents the typical XRD patterns for the surface of SEVA-C samples before and after growing the $\mathrm{CaP}$ layers and for the same layers after incorporating sodium clodronate at the highest studied doses. The profile of pure sodium clodronate powder was also acquired and is, herein, presented as a reference pattern.

SEVA-C diffraction profile presents two characteristic broad peaks, detected at $2 \theta=12^{\circ}$ and $2 \theta=20^{\circ}$, assigned to its crystalline phases. ${ }^{51}$ After growing the biomimetic layers on its surface, it is possible to detect the two main characteristic peaks attributed to HA (JCPDS card 9-432). The peak at $2 \theta=26^{\circ}$ is assigned to (002) plane in the $\mathrm{CaP}$ crystalline lattice. Another important diffraction peak is detected around $2 \theta=32^{\circ}$ and is related to the overlapping of planes (211), (112), and (300). This broad peak indicates that the $\mathrm{CaP}$ structure is composed by small crystallites. Similar XRD profile was obtained after adding sodium clodronate at 0.064 and $0.32 \mathrm{mg} / \mathrm{mL}$ to the coatings. In this way, XRD technique was not suitable for detecting such low amounts of the drug in the coating. However, when incorporating the drug at concentrations of 8 and $16 \mathrm{mg} /$ $\mathrm{mL}$, several other strong reflections can be detected, as presented in Figure 5. This indicates the presence of a new crystalline phase. These peaks can be well correlated with the diffraction pattern of the drug. Nevertheless, differences between both spectra can be detected, such as the appearance of an intense peak at $2 \theta=8^{\circ}$ and a shift left of the majority of the diffraction peaks. This result indicates that sodium clodronate crystals have suffered a dimensional rearrangement during crystallization at the surface of the coating.

\section{Microhardness}

Figure 7 shows the microhardness of SEVA-C surface and of the coatings as function of the increasing concentrations of sodium clodronate. For the concentrations of 8 and 16 $\mathrm{mg} / \mathrm{mL}$, it was not possible to obtain consistent results because of the high variability of roughness caused by the sodium clodronate crystal spicules at the surface of the $\mathrm{CaP}$ coating [as presented in Figure 3(c,d)].

After coating SEVA-C samples with the biomimetic $\mathrm{CaP}$ layer, the microhardness increased from 12 to around $15 \mathrm{MPa}$. When incorporating sodium clodronate at concentrations from 0.064 to $0.32 \mathrm{mg} / \mathrm{mL}$, an increase is observed to values up to $22 \mathrm{MPa}$. In this way, the microhardness increases significantly with increasing concentration, indicating that the drug will influence the mechanical features of the coating. Sodium clodronate in the form of a salt easily precipitated in the surface and in the pores of the $\mathrm{CaP}$ coating, contributing to the structure reinforcement.

\section{Dissolution of $\mathrm{Ca}$ and $\mathrm{P}$}

It is important to investigate the solubility of the $\mathrm{CaP}$ layers because they will dictate the release profile of the drug incorporated into it. In Figure 8 are plotted the dissolution profiles of $\mathrm{Ca}$ and $\mathrm{P}$ from the studied $\mathrm{CaP}$ coatings immersed in the different media: a solution buffered to $\mathrm{pH} 7.4$ and another buffered to $\mathrm{pH}$ 3. This last solution

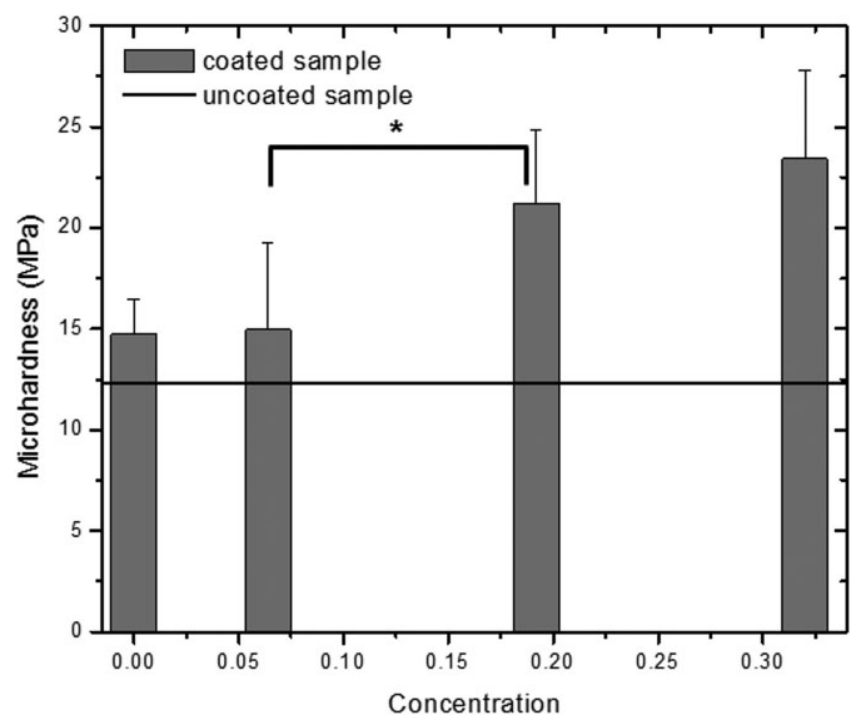

Figure 7. Microhardness of the samples with different concentrations of sodium clodronate in the $\mathrm{CaP}$ coatings. The continuous line represents the average corresponding to the microhardness at the level of the bulk substrate (uncoated sample). 


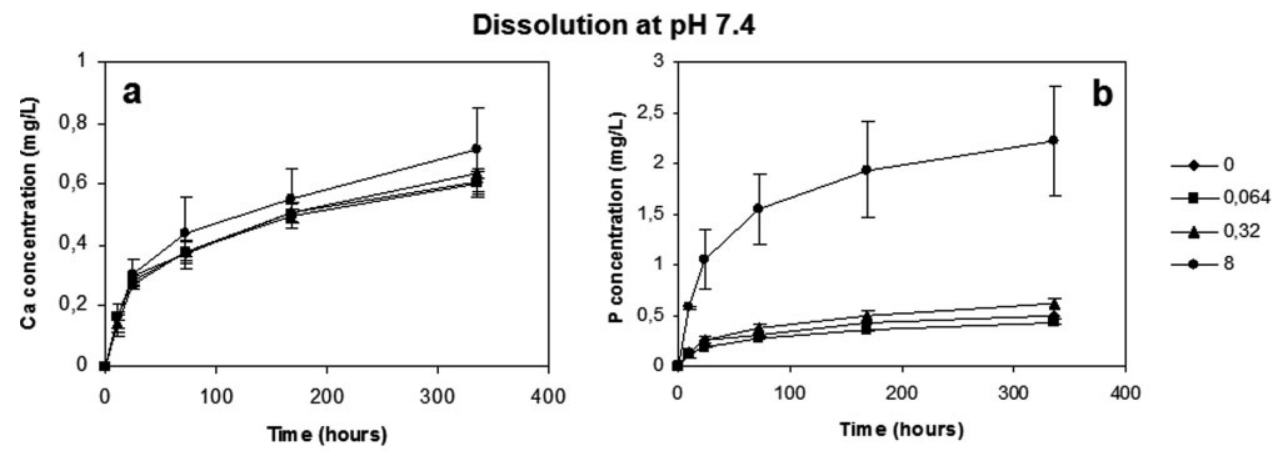

Dissolution at pH 3
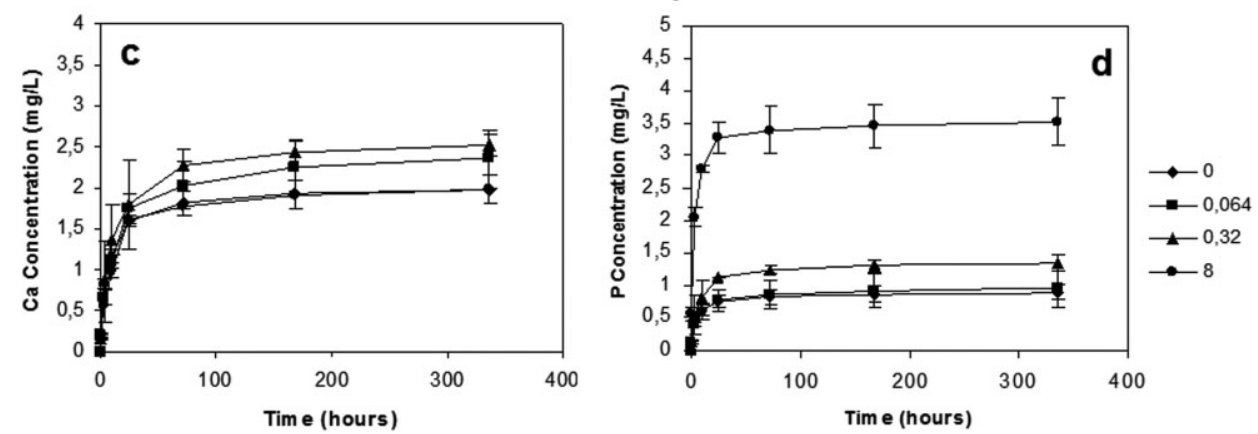

Figure 8. Dissolution profile of $\mathrm{Ca}$ and $\mathrm{P}$ in standard solutions buffered at $(\mathrm{a}, \mathrm{b})$ at $\mathrm{pH} 7.4$ and $(\mathrm{c}, \mathrm{d})$ at $\mathrm{pH} 3$.

replicates the worst in vivo circumstance resulting from the osteoclasts' activity.

When analyzing the dissolution profiles of $\mathrm{Ca}$ and $\mathrm{P}$ from the $\mathrm{CaP}$ coatings, one can observe that for the studied solutions, different dissolution kinetics are observed. The dissolution rates depend heavily on the $\mathrm{pH}$ because CaPs are more soluble in acidic than in neutral conditions. ${ }^{27,54}$ As expected, when comparing the two dissolution media, the $\mathrm{CaP}$ coatings dissolve at a higher rate when immersed in the acidic solution, at $\mathrm{pH} 3$. Nevertheless, the dissolution characteristics of $\mathrm{CaPs}$ are governed by a large number of other factors that are related either with the in vitro solution environment or with the properties of the material. In addition to the $\mathrm{pH}$, the environmental factors include the type and concentration of the buffered or unbuffered solutions, the degree of saturation, ionic strength, and so forth; the material properties include chemical composition, crystallinity, crystal particle size, density, and so forth. ${ }^{55}$

By comparing the dissolution profiles of $\mathrm{Ca}$ at $\mathrm{pH} 7.4$ [Figure 8(a)], it is possible to observe that the trend of the curves is quite similar, independent of the amount of drug present in the $\mathrm{CaP}$ coating. Because the dissolution kinetics was not significantly altered with the presence of the drug, it means that the coating stability was not compromised. When concerning the dissolution profile of $\mathrm{P}$ at $\mathrm{pH} 7.4$ [Figure 8(b)] this trend is also present, with exception to the case were $8 \mathrm{mg} / \mathrm{mL}$ of sodium clodronate was incorporated in the coating. In this case, the amount of $\mathrm{P}$ detected results not only from the dissolution of the $\mathrm{CaP}$ coating but also from the release of sodium clodronate, which has contributed significantly to the total $\mathrm{P}$ measured. The dissolu- tion rate of $\mathrm{Ca}$ and $\mathrm{P}$ is higher during the first 24 hours. This can be correlated with nature of the CaP coatings. In a dissolution study by Zhang et al., ${ }^{56}$ using the same Tris$\mathrm{HCl}$ solution, it has been clearly demonstrated that at an early stage of the dissolution, the process is governed by the morphology, crystallinity, and crystal size of the $\mathrm{CaP}$ layers. Because the $\mathrm{CaP}$ coatings are constituted by small crystallites, there will be a high surface contact area with the solution (the specific area), which will favor the dissolution process. With time, the dissolution rate decreases and other factors became rather important, as for example, the ionic product of the surrounding medium. The increase of dissolved $\mathrm{Ca}$ and $\mathrm{P}$ in solution will favor some degree of reprecipitation, which can also contribute to the decrease in the dissolution rate.

The dissolution profiles of $\mathrm{Ca}$ and $\mathrm{P}$ at $\mathrm{pH} 3$ [Figure $8(\mathrm{c}, \mathrm{d})$ ] indicate that after 24 hours, the CaP coatings were completely dissolved. Furthermore, in this case, the dissolution kinetics was not significantly altered with the presence of sodium clodronate, which means that the coating initial stability was preserved. Again, in case of the coatings incorporating $8 \mathrm{mg} / \mathrm{mL}$ of sodium clodronate, the released amount of $\mathrm{P}$ was higher.

\section{Sodium Clodronate Release Profiles}

The release profiles of sodium clodronate, incorporated at a concentration of $8 \mathrm{mg} / \mathrm{mL}$, in the two studied solutions are plotted in Figure 9. The release profiles at concentrations lower than this value were below the HPLC detection limit. 

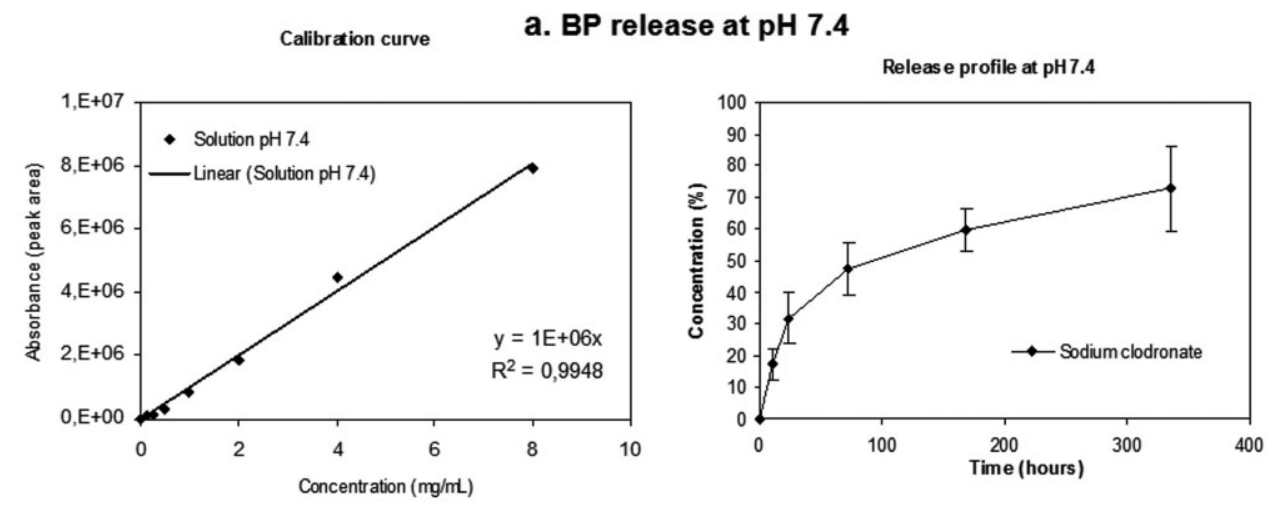

b. $\mathrm{BP}$ release at $\mathrm{pH} 3$
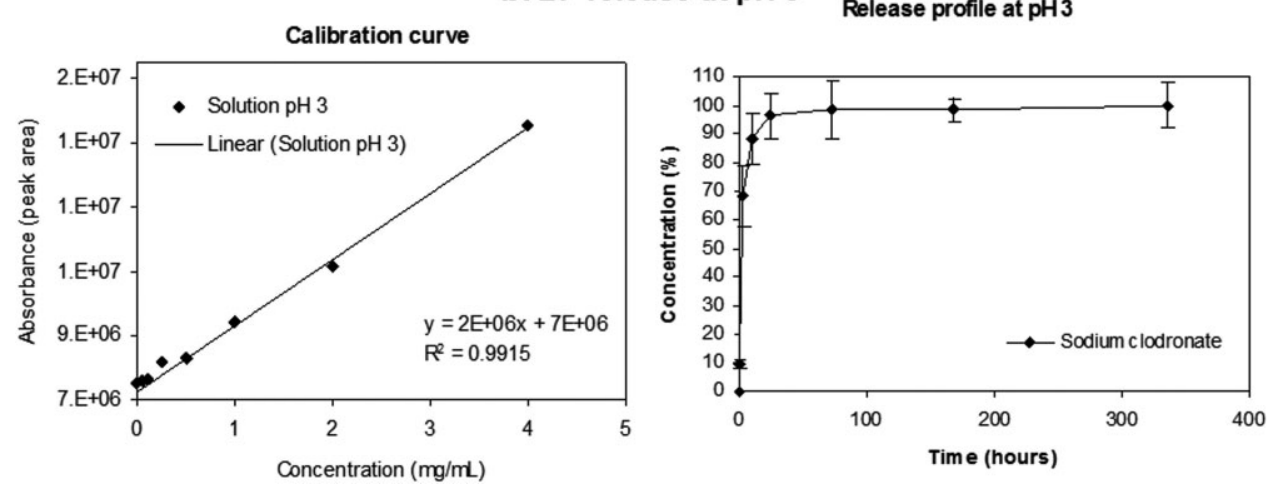

Figure 9. Calibration curves of sodium clodronate and respective release profiles in (a) a solution buffered at $\mathrm{pH} 7.4$ and (b) a solution buffered at $\mathrm{pH} 3$.

The release profile of sodium clodronate obtained in the solution buffered at $\mathrm{pH} 7.4$ [Figure 9(a,b)] follows the same trend of the $\mathrm{P}$ release presented in Figure 8(b). Around $30 \%$ of the drug is released in the first 24 hours. After 14 days, $70 \%$ of the drug was released, the remainder being incorporated in the structure of the $\mathrm{CaP}$ layer, possibly due to a reprecipitation phenomenon. ${ }^{56}$

The sodium clodronate release profile at $\mathrm{pH} 3$ [Figure $9(\mathrm{c}, \mathrm{d})]$ indicates that the entire drug is released in the first 24 hours of the experiment. Again, this result is consistent with the correspondent dissolution profile of $\mathrm{P}$ presented in Figure 8(d). At this time period, all the $\mathrm{CaP}$ is completely dissolved. The drastic effect of this solution simulates the osteoclastic digestion, which, in vivo, would be characterized by the release of citric acid in the surface of the coating and the formation of the so-called resorption pits. ${ }^{57}$ In this extreme situation, the stability of the $\mathrm{CaP}$ is very low, leading to total dissolution. Further in vitro osteoclasts studied will help to determine the stability of the $\mathrm{CaP}$ coatings in the presence of these cells.

\section{Preliminary Evaluation of the Cell Adhesion and Proliferation}

Figure 10 presents SEM micrographs of the morphology of the osteoblasts after 3 days of seeding as function of time and concentration of sodium clodronate. In Figure 11 are plotted the results concerning the cell viability (MTS) for the different times and concentrations of BP studied.

The incorporation of sodium clodronate on the $\mathrm{CaP}$ coating had a significant influence on the adhesion of the cells onto its surface. This can be clearly observed in the example presented in Figure 10 after 3 days of culture, when 0.064 and $0.32 \mathrm{mg} / \mathrm{mL}$ were present in the $\mathrm{CaP}$ coating. With the presence of the $\mathrm{BP}$ incorporated in the $\mathrm{CaP}$ coating at these doses, the cells presented a more flatten morphology, reflecting higher number of adhesion points to the surface. This behavior indicates a superior affinity to this type of surface compared with the cells that adhered to the CaP-coated surfaces but without the BP. For the higher concentrations of drug used, that is, 8 and $16 \mathrm{mg} /$ $\mathrm{mL}$, a decrease in the cell number was observed, and the cells presented a more round morphology (data not shown), indicating that at these levels sodium clodronate induced a toxic behavior.

Based on the MTS assay (Figure 11), BP stimulated cellular proliferation, and this effect was strongly dependent on the dose and on the coating type. The effect of the drug followed a sigmoid curve, causing inhibition of cellular activity at the highest dose studied and peaked at $0.32 \mathrm{mg} /$ $\mathrm{mL}$. Along the time, it was also observed that a sigmoid curve peaked at day 5 and decreased at day 7 . 

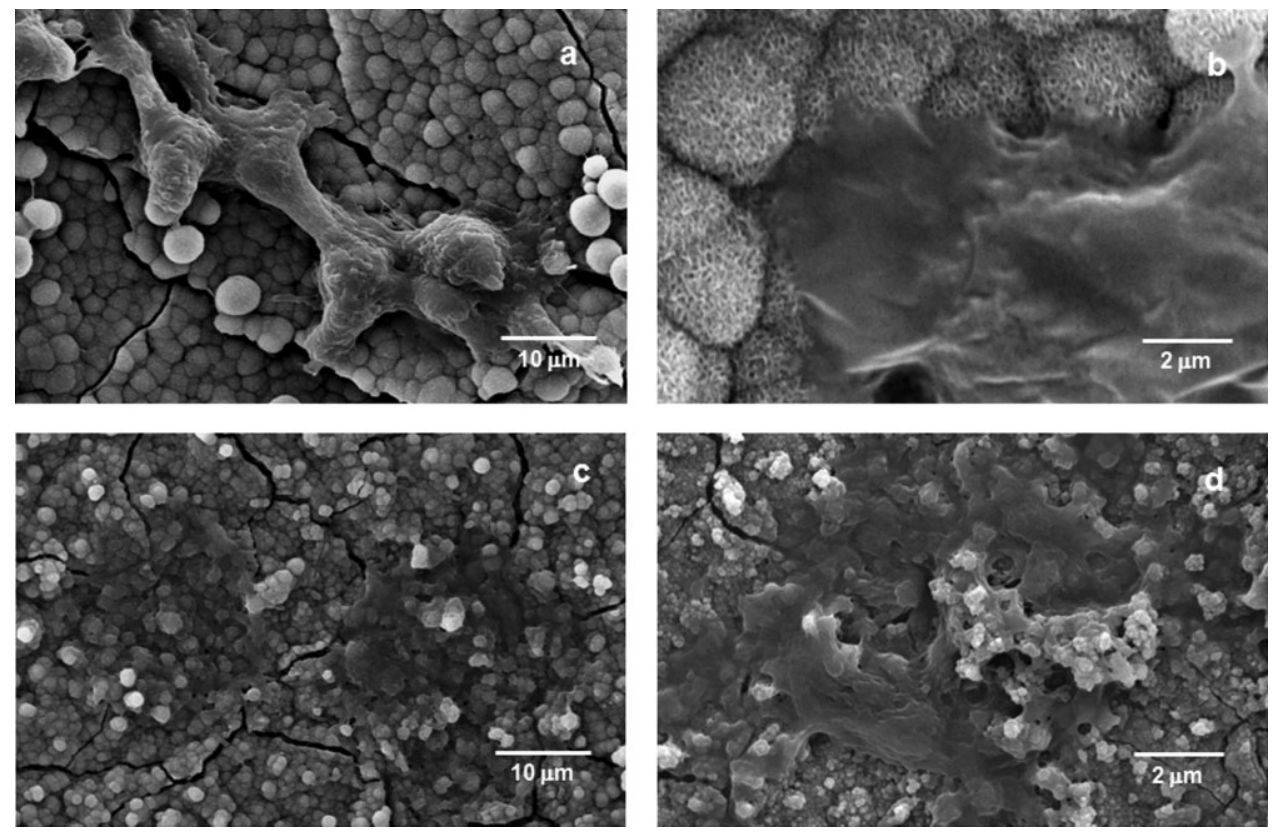

Figure 10. SEM micrographs osteoblast-like cells (SaOs-2) after 3 days in culture of showing the adhesion onto the surfaces of the apatite coatings: (a,b) without incorporation of sodium clodronate, and after incorporation of sodium clodronate at (c) $0.064 \mathrm{mg} / \mathrm{mL}$ and (d) $0.32 \mathrm{mg} / \mathrm{mL}$.

\section{DISCUSSION}

Sodium clodronate could be successfully incorporated, at different doses, in the structure of a biomimetic CaP layer formed by a sodium silicate process. This initial study was aimed at evaluating the effects of this BP (i) on the structure and in vitro stability of the CaP layers; and (ii) on the growth and function of a human osteoblast cell line, because there is still little information available on the interaction between BPs and this type of cells. In addition to defining the minimum dose to be incorporated in the $\mathrm{CaP}$ coating, it was also possible to detect a stimulatory effect of the osteoblastic activity when the ideal dose was incorporated.

The properties and composition of the produced biomimetic CaP layers were tailored in previous studies ${ }^{15,58}$ and have dictated the type of interaction with the drug and its loading efficiency. In fact, the choice of the adequate $\mathrm{CaP}$ to be used as a carrier for the drug is an important aspect for an effective incorporation. The processing route for obtaining the $\mathrm{CaP}$ is also a relevant aspect. Although known to be stable under most chemical conditions, BPs decompose at relatively low temperatures $\left(200^{\circ} \mathrm{C}\right),{ }^{59}$ which makes most coating techniques, as for example plasmaspray or sol-gel, inapplicable for coprecipitation. In these cases, a postloading methodology has been an adopted solution, ${ }^{60-62}$ which showed limited success. Because of the more crystalline and dense nature of the $\mathrm{CaP}$ coatings, the BP could only be incorporated at the outermost surface. Some authors ${ }^{62,63}$ have tried to overcome this problem by coprecipitating carbonated $\mathrm{CaP}$ layers with the $\mathrm{BP}$ over their highly crystalline CaP substrates. In a recent study,
Peter et al. ${ }^{63}$ proposes to coprecipitate pamidronate with a $\mathrm{CaP}$ coating from an SBF solution onto a preformed plasma-sprayed coating. The efficiency of this method was, however, limited. Plasma-sprayed HA presents a less reactive surface and usually a more compact structure when comparing with the currently proposed coating technique. Therefore, the drug was only incorporated in the layer of carbonated $\mathrm{CaP}$, which was more reactive to the drug. In a study performed by Seshima et al. ${ }^{60}$ it was demonstrated that the porosity (specific surface area) and crystal size of a $\mathrm{CaP}$ have a profound influence in its solubility and consequently in the ability to incorporate/release the BPs. CaPs with lower crystal size and higher specific surface area will present a higher solubility as well as a higher ability for incorporating the BP. This effect was also experienced by

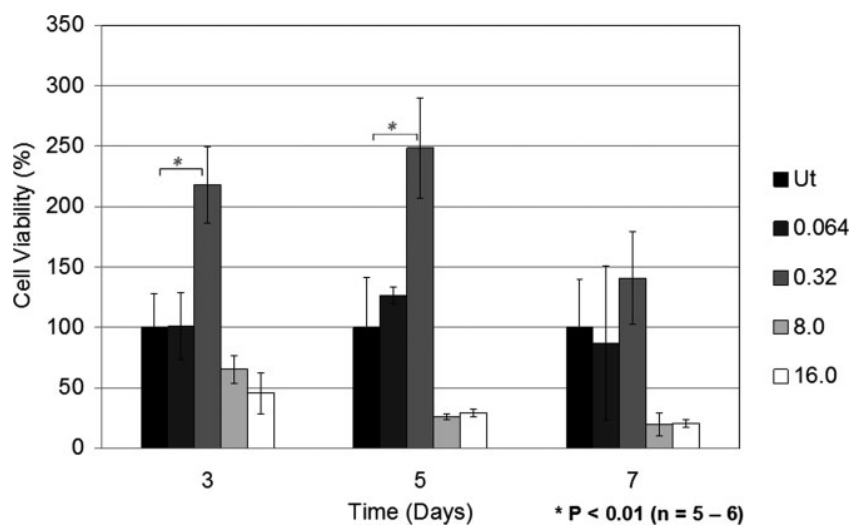

Figure 11. Quantification of the cell viability after different periods of culture on apatite coatings as function of sodium clodronate content. 
Josse et al. ${ }^{61}$ when incorporating the BP zoledronate onto different $\mathrm{CaP}$ compounds. By using mainly ${ }^{31} \mathrm{P}$ NMR spectroscopy, two different association modes have been observed, according to the nature of the $\mathrm{CaP}$ support and/ or the initial concentration of the zoledronate solution. $\beta$-Tricalcium phosphate $(\beta$-TCP) and mixtures of HA and $\beta$-TCP seem to promote zoledronate-containing crystal formation. On the other hand, at low concentrations, calciumdeficient CaPs seem to undergo chemisorption of the drug through a surface adsorption process, due to $\mathrm{PO}_{3}$ for $\mathrm{PO}_{4}$ exchange.

In our study, we were able to promote the interaction of different amounts of sodium clodronate with a biomimetic $\mathrm{CaP}$ layer because of its partially amorphous and nanocrystalline nature. It was possible to detect the presence of this drug by SEM/EDS, TF-XRD, and FTIR analysis when incorporated at concentrations of 8 and $16 \mathrm{mg} / \mathrm{L}$. However, for these high concentration levels, the majority of the drug detected resulted from the precipitation of crystal spicules of the drug at the surface of the CaP layer during drying. Nevertheless, at higher magnifications, it is possible to detect a modification of the $\mathrm{CaP}$ nanocrystalline structure, indicating that a structural rearrangement has occurred probably due to a dissolution and reprecipitation phenomena in the presence of the drug. ${ }^{56}$ However, the extent of this modification did not significantly alter the overall structural stability of the $\mathrm{CaP}$ coatings, as it can be clearly indicated by the similar dissolution profiles at $\mathrm{pHs} 7.4$ and 3. When $8 \mathrm{mg} / \mathrm{mL}$ of $\mathrm{BP}$ is incorporated in the $\mathrm{CaP}$ coating, after 14 days of release, around $30 \%$ of the drug remained in its structure, indicating that a chemical interaction is most certainly occurring because, like other BPs, sodium clodronate has a great affinity to $\mathrm{Ca}$ ions by forming complexes. ${ }^{25,26,64}$ The type of interactions between this drug and $\mathrm{CaP}$ layer will be further investigated by NMR studies.

At lower concentrations (0.064 and $0.32 \mathrm{mg} / \mathrm{mL})$, sodium clodronate was not detected by the techniques mentioned earlier. Nevertheless, it was able to influence the mechanical properties of the coating toward an increase of the microhardness of the surface. It can be extrapolated that the presence of the drug at low amounts will influence the mechanical environment that the cells will feel when in contact with the material together with the new chemical environment. In fact, sodium clodronate incorporated on the $\mathrm{CaP}$ has influenced cellular proliferation. This effect was strongly dependent on the dose incorporated, being $0.32 \mathrm{mg} / \mathrm{mL}$ of $\mathrm{BP}$ the ideal concentration for enhancing cell viability.

Ganguli et al. ${ }^{65}$ demonstrated that the synthesis of DNA, protein, and collagen was enhanced in osteoblasts when cultured on $\mathrm{CaP}$ surfaces coated with clodronates or pamidronates, proving to have a potent proliferative effect on osteoblasts. Our preliminary studies with SaOs2 cells seem to indicate a similar response to BPs in terms of cell proliferation. Without minimizing the influ- ence of other factors, these results, although still nonconclusive, presented a good reproducibility and a good correlation between the presence of sodium clodronate on the $\mathrm{CaP}$ coatings and cell morphology (Figure 10) and viability (Figure 11). The stimulatory effect of this drug, together with the potential for inhibiting bone resorption via osteoclasts, without altering the structure of the $\mathrm{CaP}$, can make this approach very effective for improving implant-bone integration, and moreover, in applications were regeneration of the tissue is required, as in tissue engineering TE applications. This preliminary results encourage further studies, namely to test the osteoclastic activity, that will be performed in the near future. Furthermore, because of the physiological working conditions $(\mathrm{T}, \mathrm{pH})$ of this biomimetic methodology, new design strategies are currently being considered with the aim of coprecipitating this drug at an early stage of the coating process to obtain BP-containing layers for longterm controlled release. It is foreseen that the coatings incorporating their therapeutic agent can, for instances, be produced on degradable polymeric carriers for the treatment of specific bone diseases regulating the equilibrium on osteoblastic/osteoclastic activity in the direction of a regenerative effect.

\section{CONCLUSIONS}

Sodium clodronate could be successfully incorporated, at different doses, in the structure of a biomimetic $\mathrm{CaP}$ layer formed by a sodium silicate process. At lower concentrations, sodium clodronate was able to influence the mechanical properties of the coating towards an increase of the microhardness of the surface. The presence of the drug in low amounts has influenced the mechanical environment that the cells feel when in contact with the material together with the new chemical environment. This effect was strongly dependent on the dose incorporated, being $0.32 \mathrm{mg} / \mathrm{mL}$ of $\mathrm{BP}$ the ideal concentration for enhancing cell viability and osteoblastic profile. This stimulatory effect, together with the potential for inhibiting bone resorption, without altering the structure of the $\mathrm{CaP}$, can make this approach very effective for improving implant-bone integration, and moreover, in applications were regeneration of the tissue is required, as in tissue engineering TE applications.

\section{REFERENCES}

1. Liu Y, De Groot K, Hunziker EB. Osteoinductive implants: The Mise-en-scene for drug-bearing biomimetic coatings. Ann Biomed Eng 2004;32:398-406.

2. Oliveira AL, Mano JF, Reis RL. Nature-inspired calcium phosphate coatings: Present status and novel advances in the science of mimicry. Curr Opin Solid State Mater Sci 2003; 7:309-318.

3. Kohn DH. Metals in medical applications. Curr Opin Solid State Mater Sci 1998;3:309-316. 
4. Weng J, Liu Q, Wolke JG, Zhang XD, deGroot K. Formation and characteristics of the apatite layer on plasma-sprayed hydroxyapatite coatings in simulated body fluid. Biomaterials 1997; 18:1027-1035.

5. Zheng XB, Huang MH, Ding CX. Bond strength of plasmasprayed hydroxyapatite/Ti composite coatings. Biomaterials 2000;21:841-849.

6. Gledhill HC, Turner IG, Doyle C. In vitro dissolution behaviour of two morphologically different thermally sprayed hydroxyapatite coatings. Biomaterials 2001;22:695-700.

7. Reis RL, Monteiro FJ. Crystallinity and structural changes in HA plasma-sprayed coatings induced by cyclic loading in physiological media. J Mater Sci: Mater Med 1996;7:407411.

8. Leonor IB, Kim HM, Balas F, Kawashita M, Reis RL, Kokubo T, Nakamura T. Functionalization of different polymers with sulfonic groups as a way to coat them with a biomimetic apatite layer. J Mater Sci: Mater Med 2007;18:19231930.

9. Tuzlakoglu K, Reis RL. Formation of bone-like apatite layer on chitosan fiber mesh scaffolds by a biomimetic spraying process. J Mater Sci: Mater Med 2007;18:1279-1286.

10. Abe Y, Kokubo T, Yamamuro T. Apatite coating on ceramics. Metals and polymers utilizing a biological process. J Mater Sci: Mater Med 1990;1:233-238.

11. Kokubo T, Kushitani H, Sakka S, Kitsugi T, Yamamuro T. Solutions able to reproduce in vivo surface-structure changes in bioactive glass-ceramic A-W. J Biomed Mater Res 1990; 24:721-734.

12. Leonor IB, Azevedo HS, Pashkuleva I, Oliveira AL, Alves $\mathrm{CM}$, Reis RL. Learning from nature how to design biomimetic calcium-phosphate coatings. In: Reis RL, Weiner S, editors. Learning from Nature How to Design New Implantable Biomaterials: From Biomineralization Fundamentals to Biomimetic Materials and Processing Routes. Drodercht: Kluwer Press; 2004. p 123-150.

13. Oliveira AL, Elvira C, Vásquez B, San Roman J, Reis RL. Surface modifications tailors the characteristics of biomimetic coatings nucleated on starch based polymers. J Mater Sci: Mater Med 1999;10:827.

14. Oliveira AL, Leonor IB, Malafaya PB, Alves CM, Azevedo HS, Reis RL. Tailoring the bioactivity of natural origin inorganic-polymeric based systems. Bioceramics 2003;15:240-242.

15. Oliveira AL, Malafaya PB, Reis RL. Sodium silicate gel as a precursor for the in vitro nucleation and growth of a bonelike apatite coating in compact and porous polymeric structures. Biomaterials 2003;24:2575-2584.

16. Nagano M, Nakamura T, Kokubo T, Tanahashi M, Ogawa M. Differences of bone bonding ability and degradation behaviour in vivo between amorphous calcium phosphate and highly crystalline hydroxyapatite coating. Biomaterials 1996; 17:1771-1777.

17. Radin S, Campbell JT, Ducheyne P, Cuckler JM. Calcium phosphate ceramic coatings as carriers of vancomycin. Biomaterials 1997; 18:777-782.

18. Campbell AA, Song L, Li XS, Nelson BJ, Bottoni C, Brooks DE, DeJong ES. Development, characterization, and antimicrobial efficacy of hydroxyapatite-chlorhexidine coatings produced by surface-induced mineralization. J Biomed Mater Res 2000;53:400-407.

19. Stigter M, de Groot K, Layrolle P. Incorporation of tobramycin into biomimetic hydroxyapatite coating on titanium. Biomaterials 2002;23:4143-4153.

20. Body JJ, Bartl R, Burckhardt P, Delmas PD, Diel IJ, Fleisch H, Kanis JA, Kyle RA, Mundy GR, Paterson AH, Rubens RD. Current use of bisphosphonates in oncology. International Bone and Cancer Study Group. J Clin Oncol 1998;16:38903899.
21. Mastrandrea LD, Albini CH. Bisphosphonate treatment of tumor-induced hypercalcemia in a toddler: Case report and review of related literature. Endocr Pract 2006;12:670-675.

22. Eekhoff ME, Zwinderman AH, Haverkort DM, Cremers SC, Hamdy NA, Papapoulos SE. Determinants of induction and duration of remission of Paget's disease of bone after bisphosphonate (olpadronate) therapy. Bone 2003;33:831-838.

23. Rodan GA, Martin TJ. Therapeutic approaches to bone diseases. Science 2000;289:1508-1514.

24. Rodan GA, Fleisch HA. Bisphosphonates: Mechanisms of action. J Clin Invest 1996;97:2692-2696.

25. Fleisch H. Bisphosphonates: Mechanisms of action. Expert Opin Ther Patents 2001;11:1371-1381.

26. Ezra A, Golomb G. Administration routes and delivery systems of bisphosphonates for the treatment of bone resorption. Adv Drug Deliv Rev 2000;42:175-195.

27. Henneman ZJ, Nancollas GH, Ebetino FH, Russell RG, Phipps RJ. Bisphosphonate binding affinity as assessed by inhibition of carbonated apatite dissolution in vitro. J Biomed Mater Res A 2008;85:993-1000.

28. Fisher JE, Rodan GA, Reszka AA. In vivo effects of bisphosphonates on the osteoclast mevalonate pathway. Endocrinology 2000;141:4793-4796.

29. Nishikawa M, Akatsu T, Katayama Y, Yasutomo Y, Kado S, Kugal N, Yamamoto M, Nagata N. Bisphosphonates act on osteoblastic cells and inhibit osteoclast formation in mouse marrow cultures. Bone 1996;18:9-14.

30. Adami S, Zamberlan N. Adverse effects of bisphosphonatesA comparative review. Drug Safety 1996;14:158-170.

31. Sutton SC, Engle K, Fix JA. Intranasal delivery of the bisphosphonate alendronate in the rat and dog. Pharm Res 1993;10:924-926.

32. Duncan AR. The use of subcutaneous pamidronate. J Pain Symptom Manage 2003;26:592-593.

33. Osterman T, Lauren L. Level of clodronate in bone after single and repeated subcutaneous injections in rats. Pharmacol Toxicol 1991;69:369-371.

34. Walker P, Watanabe S, Lawlor P, Hanson J, Pereira J, Bruera E. Subcutaneous clodronate: A study evaluating efficacy in hypercalcemia of malignancy and local toxicity. Ann Oncol 1997;8:915-916.

35. Conte P, Guarneri V. Safety of intravenous and oral bisphosphonates and compliance with dosing regimens. Oncologist 2004;9(suppl 4):28-37.

36. Venesmaa PK, Kröger HP, Miettinen HJ, Jurvelin JS, Suomalainen OT, Alhav EM. Alendronate reduces periprosthetic bone loss after uncemented primary total hip arthroplasty: A prospective randomized study. J Bone Miner Res 2001; 16:2126-2131.

37. Nehme A, Maalouf G, Tricoire JL, Giordano G, Chiron P, Puget J. Effect of alendronate on periprosthetic bone loss after cemented primary total hip arthroplasty: A prospective randomized study. Revue De Chirurgie Orthopedique Et Reparatrice De L Appareil Moteur 2003;89:593-598.

38. Yamaguchi K, Masuhara K, Yamasaki S, Nakai T, Fuji T. Cyclic therapy with etidronate has a therapeutic effect against local osteoporosis after cementless total hip arthroplasty. Bone 2003;33:144-149.

39. Venesmaa PK, Kröger HP, Miettinen HJ, Jurvelin JS, Suomalainen OT, Alhava EM. Monitoring of periprosthetic BMD after uncemented total hip arthroplasty with dual-energy Xray absorptiometry--a 3-year follow-up study. J Bone Miner Res 2001;16:1056-1061.

40. Kajiwara H, Yamaza T, Yoshinari M, Goto T, Iyama S, Atsuta I, Kido MA, Tanaka T. The bisphosphonate pamidronate on the surface of titanium stimulates bone formation around tibial implants in rats. Biomaterials 2005;26:581587. 
41. Yoshinari M, Oda Y, Inoue T, Matsuzaka K, Shimono M. Bone response to calcium phosphate-coated and bisphosphonate-immobilized titanium implants. Biomaterials 2002;23: 2879-2885.

42. Peter B, Pioletti DP, Laib S, Bujoli B, Pilet P, Janvier P, Guicheux J, Zambelli PY, Bouler JM, Gauthier O. Calcium phosphate drug delivery system: Influence of local zoledronate release on bone implant osteointegration. Bone 2005; 36:52-60.

43. Reis RL, Cunha AM. Characterization of two biodegradable polymers of potential application within the biomaterials field. J Mater Sci: Mater Med 1995;6:786-792.

44. Reis RL, Cunha AM, Allan PS, Bevis MJ. Mechanical behavior of injection-molded starch-based polymers. Polym Adv Technol 1996;7:784-790.

45. Sousa RA, Reis RL, Cunha AM, Bevis MJ. Processing and properties of bone-analogue biodegradable and bioinert polymeric composites. Compos Sci Technol 2003;63:389-402.

46. Reis RL, Mendes SC, Cunha AM, Bevis MJ. Processing and in vitro degradation of starch/EVOH thermoplastic blends. Polym Int 1997;43:347-352.

47. Oliveira AL, Malafaya PB, Costa SA, Sousa RA, Reis RL. Micro-computed tomography (mu-CT) as a potential tool to assess the effect of dynamic coating routes on the formation of biomimetic apatite layers on 3D-plotted biodegradable polymeric scaffolds. J Mater Sci: Mater Med 2007;18:211-223.

48. Plosker GL, Goa KL. Clodronate-A review of its pharmacological properties and therapeutic efficacy in resorptive bone disease. Drugs 1994;47:945-982.

49. Oliveira AL, Santos MI, Pedro AA, Reis RL. Bisphosphonates incorporated on a Ca-P biomimetic coating produced by a sodium silicate based methodology stimulate osteoblastic activity. Bioceramics 2005;17:615-618.

50. Azevedo HS, Gama FM, Reis RL. In vitro assessment of the enzymatic degradation of several starch based biomaterials. Biomacromolecules 2003;4:1703-1712.

51. Reis RL, Cunha AM. Characterization of two biodegradable polymers of potential application within the biomaterials field. J Mater Sci: Mater Med 1995;6:786-792.

52. Rehman I, Bonfield W. Characterization of hydroxyapatite and carbonated apatite by photo acoustic FTIR spectroscopy. J Mater Sci: Mater Med 1997;8:1-4.

53. Oliveira AL, Malafaya PB, Reis RL. Sodium silicate gel induced self-mineralization of different compact and porous polymeric structures. Bioceramics 2000;192:75-78.
54. Budz JA, Nancollas GH. The mechanism of dissolution of hydroxyapatite and carbonated apatite in acidic solutions. J Cryst Growth 1988;91:490-496.

55. Ducheyne $\mathrm{P}$, Radin S, King L. The effect of calciumphosphate ceramic composition and structure on in vitro behavior. I. Dissolution. J Biomed Mater Res 1993;27:2534.

56. Zhang Q, Chen J, Feng J, Cao Y, Deng C, Zhang X. Dissolution and mineralization behaviors of HA coatings. Biomaterials 2003;24:4741-4748.

57. Matsuoka H, Nakamura T, Takadama H, Yamada S, Tamura J, Okada Y, Oka M, Kokubo T. Osteoclastic resorption of bone-like apatite formed on a plastic disk as an in vitro assay system. J Biomed Mater Res 1998;42:278-285.

58. Oliveira AL, Reis RL. Pre-mineralisation of starch/polycrapolactone bone tissue engineering scaffolds by a calciumsilicate-based process. J Mater Sci: Mater Med 2004;15: 533-540.

59. Ezra A, Golomb G. Administration routes and delivery systems of bisphosphonates for the treatment of bone resorption. Adv Drug Deliv Rev 2000;42:175-195.

60. Seshima H, Yoshinari M, Takemoto S, Hattori M, Kawada E, Inoue T, Oda Y. Control of bisphosphonate release using hydroxyapatite granules. J Biomed Mater Res B Appl Biomater 2006;78:215-221.

61. Josse S, Faucheux C, Soueidan A, Grimandi G, Massiot D, Alonso B, Janvier P, Laib S, Pilet P, Gauthier O. Novel biomaterials for bisphosphonate delivery. Biomaterials 2005;26: 2073.

62. Yoshinari M, Oda Y, Ueki H, Yokose S. Immobilization of bisphosphonates on surface modified titanium. Biomaterials 2001;22:709-715.

63. Peter B, Gauthier O, Laib S, Bujoli B, Guicheux J, Janvier P, van Lenthe GH, Muller R, Zambelli PY, Bouler JM, Pioletti DP. Local delivery of bisphosphonate from coated orthopedic implants increases implants mechanical stability in osteoporotic rats. J Biomed Mater Res 2006;76:133-143.

64. Kontturi M, Peraniemi S, Vepsalainen JJ, Ahlgren M. X-ray diffraction study of bisphosphonate metal complexes: $\mathrm{Mg}$ and $\mathrm{Ca}$ complexes of (dichloromethylene)bisphosphonic acid $\mathrm{P}, \mathrm{P}^{\prime}$ diisopropyl ester. Polyhedron 2005;24:305.

65. Ganguli A, Henderson C, Grant MH, Meikle ST, Lloyd AW, Goldie I. The interactions of bisphosphonates in solution and as coatings on hydroxyapatite with osteoblasts. J Mater Sci: Mater Med 2002;13:923-931. 